\title{
Sodium butyrate does not decrease the evolution of precancerous lesions in rats ${ }^{1}$
}

\author{
Butirato de sódio não diminui a evolução de lesões pré-neoplásicas em ratos
}

\author{
Fernanda Guimarães Drummond e Silva ${ }^{\mathrm{I}}$, Luisa Costa Penna Penido ${ }^{\mathrm{I}}$, Flávia Xavier Valente ${ }^{\mathrm{I}}$, Maria Carolina Santos Mendes ${ }^{\mathrm{II}}$, \\ Damiana Diniz Rosa ${ }^{\text {III }}$, Maria Beatriz Abreu Glória ${ }^{\text {IV }}$, Maria do Carmo Gouveia Peluziov

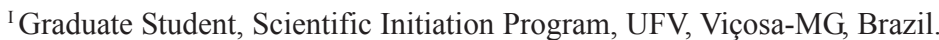

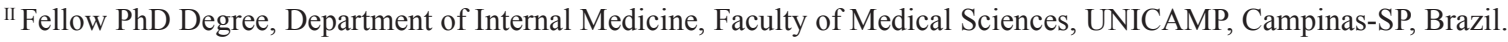

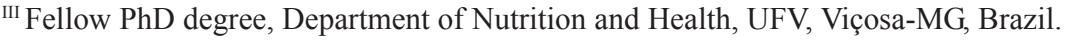 \\ ${ }^{\mathrm{IV}} \mathrm{PhD}$, Associate Professor, Department of Food, School of Pharmacy, Federal University of Minas Gerais (UFMG), Belo Horizonte-MG, Brazil. \\ ${ }^{v} \mathrm{PhD}$, Associate Professor, Department of Nutrition and Health, UFV, Viçosa-MG, Brazil.
}

\begin{abstract}
Purpose: To evaluate the preventive effect of sodium butyrate in the appearance of aberrant crypt foci (ACF) in rats after induction with the carcinogen 1,2-dimethylhydrazine (DMH). Methods: Forty Wistar rats were separated into four groups (n=10) distributed as follows: control 1, control 2, butyrate 1 and butyrate 2 . The groups control 1 and butyrate 1 remained under experimentation for 4 weeks, while the groups control 2 and butyrate 2 remained for 8 weeks. In the first four weeks, the animals of the control groups received water ad libitum and the animals of the butyrate groups received a sodium butyrate solution (3.4\%) ad libitum. Injections of the drug 1,2-dimethylhydrazine were applied during the two first weeks of the experiment in all the animals, concurrently with the application of sodium butyrate. The large intestine of the animals was removed, for the analysis of the ACF and of the content of polyamines. The animal feces were collected for the analysis of the SCFA profile. Results: The spermidine presented a higher concentration in the group butyrate 2 in comparison to the group control 2 . There was a significant difference in the concentration value $(\mu \mathrm{mol} / \mathrm{mL}) \mathrm{of}$ acetate in comparison to the groups control 2 and butyrate 2. Conclusion: The use of sodium butyrate together with the induction of colorectal cancer was not effective in the prevention of the disease progression.
\end{abstract}

Key words: Colonic Neoplasms. Precancerous Conditions. Butyrates. Rats.

\section{RESUMO}

Objetivo: Avaliar o efeito preventivo do butirato de sódio no surgimento de focos de cripta aberrante (FCA) em ratos após a indução com o carcinógeno 1,2-dimetilhidrazina. Métodos: Quarenta ratos foram divididos em quatro grupos, com dez animais em cada. Os grupos controle 1 e butirato 1 ficaram em experimentação por 4 semanas e os grupos controle 2 e butirato 2 por oito semanas. Nas primeiras quatro semanas, os animais dos grupos controle receberam água ad libitum e os animais dos grupos butirato receberam solução de butirato de sódio (3,4\%) ad libitum. Em todos os animais foram aplicadas quatro injeções subcutâneas da droga 1,2-dimetilhidrazina nas duas primeiras semanas, concomitante a administração do butirato de sódio. Foi retirado o intestino grosso dos animais, para análise dos FCA e do teor de poliaminas. As fezes dos animais foram recolhidas para análise do perfil de AGCC. Resultados: A espermidina apresentou maior concentração no grupo butirato 2 em relação ao grupo controle 2. Foi encontrada diferença significativa no valor da concentração de acetato quando comparado os grupos controle 2 e butirato 2. Conclusão: A utilização do butirato de sódio concomitante à indução do câncer colorretal não se mostrou efetiva na prevenção da progressão da doença.

Descritores: Neoplasias do Colo. Lesões Pré-Cancerosas. Butiratos. Ratos.

${ }^{1}$ Research performed at the Department of Nutrition and Health, Federal University of Viçosa (UFV), Minas Gerais. Brazil.

\section{Introduction}

The colorectal cancer (CRC) is characterized by the uncontrolled growth of neoplastic cells due to many genetic errors that accumulate in the cells over the years, with invasive potential, which may propagate for other regions ${ }^{1}$. According to Stevens et $a l .^{2}$, the first indication of the development of cancer is the presence of aberrant crypt foci (ACF) of precancerous lesions.
Polyamines are very important for human cancers and are widely requested in the tumor growth process. The ability of the cells to synthesize polyamines may not be enough for all the demand and, in these cases, they may derive from external sources, such as the diet and microorganisms present in the intestinal tract ${ }^{3,4}$. Polyamines, according to the diversity of the functions in the cell metabolism and proliferation, are requested in great amounts in tissues with fast growth and development. Increases in the 
concentration of spermidine and putrescine may occur in response to brain, liver of intestinal injury, cerebral ischemia, hormone effects or growth factors ${ }^{4}$.

A regulatory mechanism of the concentration of intracellular polyamine is its capture through the intestinal cells. After being captured, it is preferably taken to the tumors and proliferating tissues ${ }^{3}$. Therefore, the inhibition of the biosynthesis of polyamines in cancerous tissue is one of the main objectives of the researches involving polyamines ${ }^{3,4}$.

It is believed that an adequate diet could avoid the occurrence of three to four million new cases of cancer a year. People who consume diets rich in fruits and vegetables seem to have a low incidence of many kinds of cancer, including $\mathrm{CRC}^{5}$.

According to Rose et $a l .{ }^{6}$, fibers could work as anticarcinogenic components by several mechanisms. One of them includes the fermentation of soluble fibers in the colon by the intestinal microflora producing short-chain fatty acids (SCFA) ${ }^{6}$. The SCFA include acetate, propionate, butyrate and isobutyrate, which are fuels for the cells of the colonic mucosa ${ }^{7}$.

The SCFA can also be transferred to the bloodstream by a mechanism still unknown, in which they interact with two receptors attached to the protein $\mathrm{G}$, the GPR43, which joins to acetate and propionate and the GPR41, which joins to butyrate and isobutyrate ${ }^{8}$.

Butyrate presents several effects on CRC prevention: apoptosis induction in cells with DNA mutation ${ }^{9}$; decrease in the expression of inflammatory proteins, such as $\mathrm{COX}-2^{10}$; angiogenesis inhibition ${ }^{11}$; inhibition of the transcription of mitotic factors, of which cyclin D1 depends, thus inhibiting the phosphorylation of the retinoblastoma protein $(\mathrm{Rb})$, blocking the cell cycle and retaining the cells in the phase $\mathrm{G}_{1}$; promotion of the expression of the cyclin-inhibiting protein at p21 in cells with injuries in their DNA with the retention of the cell proliferation; stimulation of the production of mucin-2 (MUC2), which is recognized as a preventive factor against the CRC for protecting the cell surface from variations in the intestinal environment, such as the presence of microorganisms, toxins, digestive enzymes, $\mathrm{pH}$ changes and others ${ }^{12}$

Due to several evidences of the benefits provided by butyrate in the prevention of precancerous lesions and development of CRC, the present work aimed to evaluate the preventive effect of sodium butyrate in the appearance of ACF in rats after the induction with the carcinogen 1,2-dimetylhydrazine (DMH).

\section{Methods}

\section{Animals and diets}

Forty 11-week old male Wistar rats were used. They stayed in individual cages at the temperature of $23^{\circ} \mathrm{C} \pm 2{ }^{\circ} \mathrm{C}$, in photoperiod of 12 hours.

The animals were divided into four groups so that the difference between the averages of the weights among the groups would not surpass $5 \mathrm{~g}$. They were distributed as follows: control 1 $(n=10)$, control $2(n=10)$, butyrate $1(n=10)$ and butyrate $2(n=10)$. In the first four weeks of the experiment, the animals in the control groups received water ad libitum and the animals in the butyrate groups received a sodium butyrate solution $(3.4 \%)$ ad libitum. In the four following weeks, the sodium butyrate solution for the group butyrate 2 was interrupted and all the groups received water ad libitum. All of the groups received a commercial diet $\left(\right.$ Nuvilab $\left.^{\circledR}\right)$. The diet composition was based on the American Institute of Nutrition. It was used the diet AIN93M, recommended for the maintenance of adult animals ${ }^{13}$. The consumption of the diets and the weight of the animals were monitored weekly, during the whole experiment.

The sodium butyrate solution was prepared with $34 \mathrm{~mL}$ of butyric acid (SIGMA ${ }^{\circledR}$, USA) and distilled water enough to achieve $1000 \mathrm{~mL}$, the $\mathrm{pH}$ was adjusted for approximately 7.4 with $\mathrm{NAOH}$ solution at $0,1 \mathrm{~N}^{14}$.

\section{Administration of 1,2-dimethylhydrazine and material} collection

Four subcutaneous injections of 1,2-dimethylhydrazine $\left(\mathrm{SIGMA}^{\circledR}, \mathrm{USA}\right)$ were applied at the doses of $40 \mathrm{mg} / \mathrm{Kg}$ of weight, twice a week, during the first two weeks of the experiment, for all the animals, concurrently with the administration of sodium butyrate. The 1,2-dimethylhydrazine (DMH) was prepared immediately before the use, dissolved in a $\mathrm{NaCl} 0.9 \%$ solution, with $15 \%$ of EDTA and $\mathrm{pH} 6.5^{15}$.

The animals of the groups control 1 and butyrate 1 were euthanized after four weeks and those in the groups control 2 and butyrate 2, after eight weeks, as illustrated in Figure 1. The large intestine of the animals was removed, from the cecus to the anus, for the analysis of the ACF and polyamine contents. The feces of the animals were removed for the analysis of the SCFA profile.

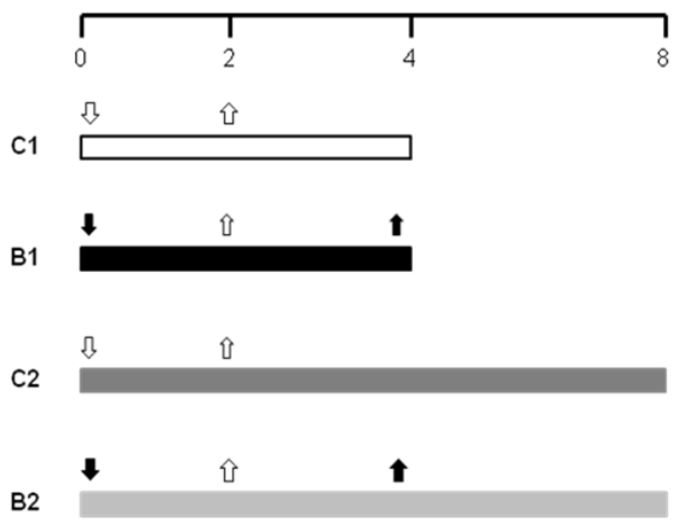

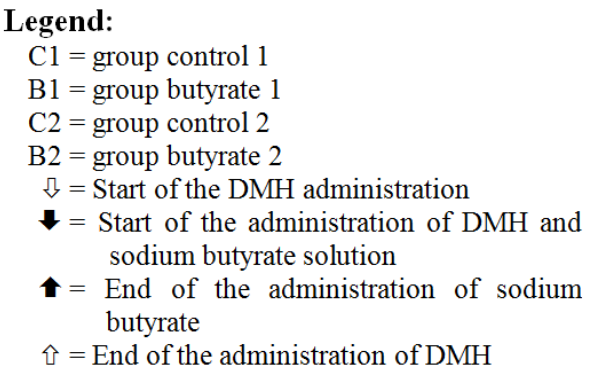

Legend:

$\mathrm{C} 2$ = group control 2

$\mathrm{B} 2$ = group butyrate 2

$\checkmark=$ Start of the $\mathrm{DMH}$ administration sodium butyrate solution

$=$ End of the administration of DMH

FIGURE 1 - Experimental design 


\section{Preparation of the tissue for the ACF counting}

The intestines of 5 animals of each group were removed and washed in a physiological saline solution, longitudinally opened by the counter-mesenteric border, placed in paraffin plaques, with the mucosa turned to the superior part of the plaque and then fixed in formaldehyde, at $10 \%$, for 24 hours. The large intestine was measured and divided into three equal fragments called proximal, medium and distal, in relation to the cecum. For the counting of ACF, it was considered only the distal segment, which was dyed in Methylene Blue Solution at $0.1 \%{ }^{16}$.

The surface of the intestinal mucosa was observed with the use of a binocular optical light microscope, with magnification of $10 \mathrm{x}$ for the identification and categorization of the ACF, according to the Bird technique ${ }^{16}$. The ACF were counted in the whole surface of the large intestine mucosa, by two observers in the double-blind manner. The categorization of the ACF was based on the number of aberrant crypt foci, in other words, foci with three or less crypts and foci with more than three crypts.

The percentage of the reduction of ACF with three or less aberrant crypts and with more than three aberrant crypts in the different weeks studied was achieved as follows: first, it was calculated the percentage of ACF presented by the group butyrate 1 , through a rule of three, where the ACF of the group control 1 was considered as $100 \%$. This result is subtracted by $100 \%$, resulting in the percentage of reduction of the group butyrate 1 in relation to the group control 1. The same procedure was performed to calculate the percentage of reduction of the group butyrate 2 in relation to the group control 2 .

\section{Quantification of the content of polyamines $(\mathrm{BH})$}

The contents of polyamines (putrescine, spermidine and spermine) and bioactive amines (histamine and cadaverine) were investigated in the large intestine, distal segment, of 5 animals from each group. The extraction of the polyamines was carried out according to Vale and Glória ${ }^{17}$. The polyamines were separated by High Perfomance Liquid Chromatography (HPLC) per ion pairing in reversed phase column and quantified by fluorimetry after post-column derivation with ftaldialdehyde and detected by fluorescence at 340 and $450 \mathrm{~nm}$ of excitation and emission, respectively ${ }^{19}$. The chromatograph used was a Shimadzu (Kyoto,
Japan) apparatus. The analyses were carried out in duplicate, and the detection limit was $0,04 \mathrm{mg} / 100 \mathrm{~g}$.

\section{Quantification of short-chain fatty acids in the feces}

The feces of all the animals were collected in the two days preceding the euthanasia and were stored at $20^{\circ} \mathrm{C}$ for further analysis of the short-chain fatty acids (acetate, propionate and butyrate). The material was extracted and analyzed according to the methodology of Smiricky-Tjardes et al. ${ }^{18}$.

\section{Statistical analysis}

It was used the SPSS (Statistical Package for the Social Sciences) software system, version 15.0. We compared group control 1 with butyrate 1 and group control 2 with butyrate 2, because the experimental times were distinct. The comparison among the groups was carried out by the Mann-Whitney test, when the data were non-parametric and by the T-test, when data were parametric. The $\mathrm{p}$ value was fixed in $5 \%(\mathrm{p}<0.05)$.

\section{Ethical considerations}

This project was approved by the Ethics Committee of the Department of Veterinary Medicine of the Federal University of Viçosa, processed 12/2009, and the experiment was carried out according to the Ethical Principles in Animal Experimentation, adopted by the Brazilian College of Animal Experimentation (COBEA).

\section{Results}

\section{Animal weight control}

During the experiment, the control group 1 presented higher weight gain in relation to the butyrate group 1 . There was a significant difference $(p<0.05)$ between the weight gain of the groups control 1 and butyrate 1 in the third and fourth weeks. It was observed that the weight gain of the group control 2 was higher than the weight gain of the group butyrate 2, except in the fifth, sixth and eighth weeks. The Figure 2 demonstrates the evolution of the weight of the animals during the 8 weeks of study.

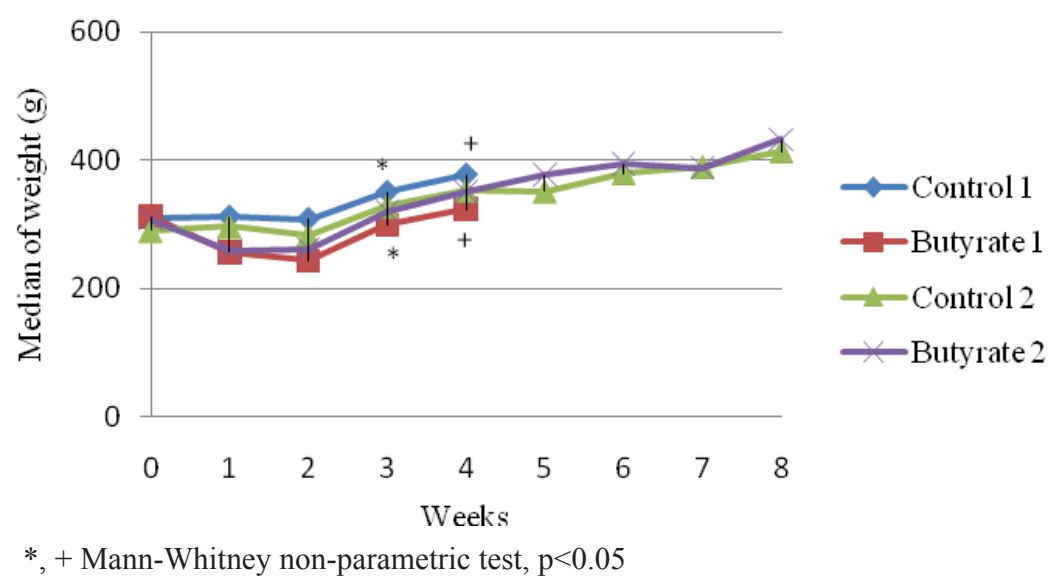

FIGURE 2 - Evolution of the weight of the animals 


\section{Number and characterization of the aberrant crypts}

The results of the counting of the aberrant crypt can be seen on Tables 1 and 2 .

TABLE 1 - Number of aberrant crypt after four weeks of study

\begin{tabular}{ccccccc}
\hline Categorization & \multicolumn{3}{c}{ Control 1 } & \multicolumn{3}{c}{ Butyrate 1} \\
\cline { 2 - 7 } of ACF & $\mathrm{n}$ & Average \pm DP & Median & Average \pm DP & Median & $\mathrm{p}^{*}$ \\
\hline$<3$ & 5 & $35.3 \pm 17.72$ & 26.0 & $25.25 \pm 21.51$ & 16.50 & 0.14 \\
$>3$ & 5 & $1.5 \pm 1.27$ & 1.5 & $1.75 \pm 1.44$ & 1.75 & 0.61 \\
Total & 10 & $35.7 \pm 19.68$ & 25.5 & $27.0 \pm 22.23$ & 17.25 & 0.14 \\
\hline
\end{tabular}

* Mann Whitney non-parametric test, $\mathrm{p}<0.05$

TABLE 2 - Number of aberrant crypt foci after eight weeks of study

\begin{tabular}{ccccccc}
\hline Categorization & \multicolumn{3}{c}{ Control 2} & \multicolumn{3}{c}{ Butyrate 2} \\
\cline { 2 - 6 } of ACF & $\mathrm{n}$ & Average $\pm \mathrm{DP}$ & Median & Average $\pm \mathrm{DP}$ & Median & $\mathrm{p}^{*}$ \\
\hline$<3$ & 5 & $15.8 \pm 12.03$ & 12.0 & $8.50 \pm 2.27$ & 16.50 & 0.22 \\
$>3$ & 5 & $9.3 \pm 11.20$ & 2.0 & $4.13 \pm 4.95$ & 2.50 & 0.46 \\
Total & 10 & $32.0 \pm 22.50$ & 20.0 & $12.88 \pm 4.29$ & 11.75 & 0.11
\end{tabular}

* Mann Whitney non-parametric test, $\mathrm{p}<0.05$

\section{Analysis of polyamines of the intestinal tissue}

The contents of polyamines are described in the Figure 3. The average concentrations ( $\mathrm{mg} / 100 \mathrm{~g}$ ) of putrescine, histamine, spermine and spermidine were similar $(\mathrm{p}>0.05)$, when compared to the control 1 and butyrate 1 . However, when the group control 2 was compared to the butyrate 2 , a significant difference was found $(p<0.05)$ among the medians of the concentrations of spermidine. The concentrations of cadaverine were not detected in any of the samples.

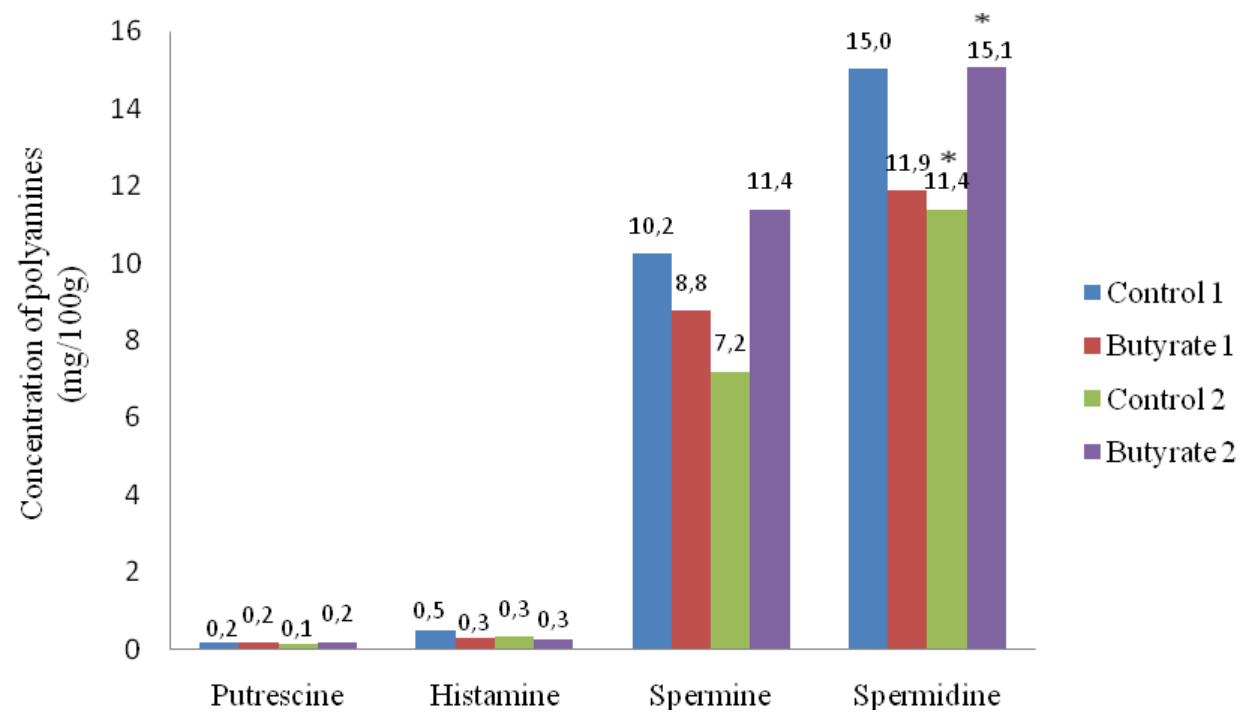

* Mann-Whitney non-parametric test, $\mathrm{p}<0.05$

FIGURE 3 - Concentrations of polyamines in the large intestine (distal segment) 
Lipid profile of short-chain fatty acids (SCFA) in the feces

The lipid profile of short-chain fatty acids: acetate, propionate and butyrate from the total feces of the animals were analyzed. A significant difference was observed $(\mathrm{p}<0.05)$ in the concentration value $(\mu \mathrm{mol} / \mathrm{mL})$ of acetate in comparison to the groups control 1 and butyrate 1 , and in comparison to the groups control 2 and butyrate 2 . The lipid profile of SCFA of the feces is demonstrated in the Figure 4.

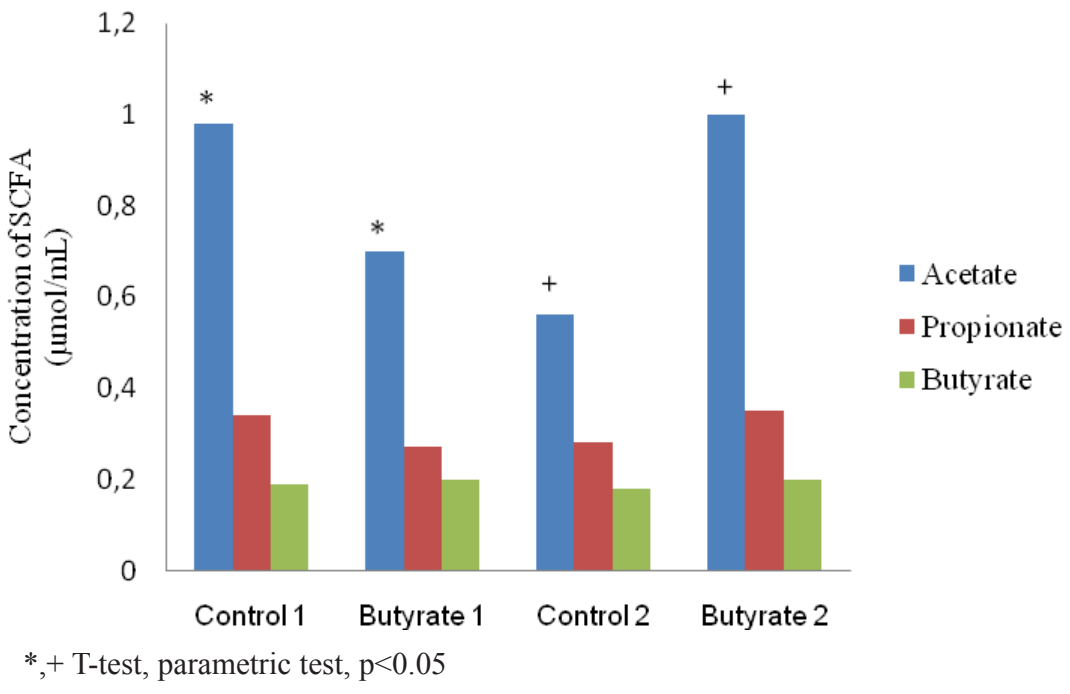

FIGURE 4 - Concentration of SCFA in the feces

\section{Discussion}

The animals presented a similar response for weight gain in the end of the experiment, demonstrating that the administration of sodium butyrate did not change their weight evolution.

The use of butyrate in the prevention of CRC has raised some controversies ${ }^{19}$. Precancerous lesions or ACF were found during the two phases of this experiment (four and eight weeks). However, there was no significant difference between the groups that received butyrate and the control groups.

Raju et al..$^{20}$ reported that factors such as the dose of the carcinogen, administration routine, time of intervention, age, sex of the animals, location, appearance of the lesions in the colon and the selection of the animal are decisive to understand the ongoing relation between the ACF development and the formation of tumors ${ }^{20}$. This is so because, according to their development stage, the ACF are heterogeneous in their molecular composition and may have their growth inhibited or stimulated by several components.

Although some studies demonstrate that butyrate presents a preventive effect, forbidding the proliferation of colonocytes $^{21}$, our work could not corroborate such ability.

The identification of ACF and its regression caused by several kinds of treatment with butyrate varies a lot. In the study of Kanna et al. $^{22}$ the identification of ACF was possible after sixteen weeks of induction with the carcinogen, concurrently with the treatment with butyrate, and decreases were verified in the precancerous lesions ${ }^{22}$. Raju et al. ${ }^{20}$ tested different doses of butyrate during five consecutive weeks; two weeks before the induction, two weeks concurrently with the administration of the carcinogen and one week after the induction ${ }^{20}$. In this study, ACF was identified 16 weeks after the beginning of the experiment and butyrate was able to decrease or increase the lesion according to the quantity applied.
High levels of polyamines are associated with the cell proliferation and the decrease in apoptosis ${ }^{23}$. The content of these compounds in the colorectal tissue with neoplasms can be up to four times higher when compared to the normal tissue ${ }^{24}$, and they can be considered a trustable biomarker for the neoplastic growth $^{25}$.

The results of this study demonstrated that the development of precancerous lesions of the groups control 1 and butyrate 1 was similar, which is corroborated by the similarity in the number of ACF in the animals of both groups and also by the similarity in the concentration of polyamines. Nevertheless, spermidine presented a higher concentration in the group butyrate 2 , in comparison to the group control 2 . This result may indicate that, in a long term, the group butyrate 2 will present a higher number of ACF, compared to the group control 2, due to the supplementation with butyrate. Our result is in accordance with Liu and $\mathrm{Xu}^{19}$, which demonstrated that, when used before the formation of de precancerous lesions, butyrate will be a potentiating agent in the formation of these lesions ${ }^{19}$.

As for the concentration of short-chain fatty acids in the feces, only acetate differed in the group butyrate 1, when compared to the control 1 and group butyrate 2, when compared to the control 2. Such result leads to the conclusion that the acids evaluated (propionate and butyrate) were more used as a source of energy by the colonocyte itself and that maybe because there is a higher concentration of butyrate in the beginning of the development of the lesion, the compound potentialized the development of precancerous lesions in the experimental period evaluated.

One of the limitations of our study was the measurement of the amount of butyrate used by the large intestine after digestion, since we had to decide to count the crypts in this tissue. Other studies should define the direct action of the SCFA in the colon. 


\section{Conclusion}

The results of the present study lead to the conclusion that the use of sodium butyrate together with the induction of the colorectal cancer was not effective in the prevention of the disease progression.

\section{References}

1. Jullumstrø E, Lydersen S, Møller B, Dahl O, Edna TH. Duration of symptoms, stage at diagnosis and relative survival in colon and rectal cancer. Eur J Cancer. 2009;45(13):2383-90.

2. Stevens RG, Swede H, Rosenberg DW. Epidemiology of colonic aberrant crypt foci: review and analysis of existing studies. Cancer Lett. 2007;252:171-83.

3. Larqué E, Sabater-Molina M, Zamora S. Biological significance of dietary polyamines. Nutrition. 2007;23(1):87-95.

4. Gerner EW, Meyskens FL Jr. Polyamines and cancer: old molecules, new understanding. Nat Rev Cancer. 2004;4(10):781-92.

5. Brouns F. Kettlitz B, Arrigoni E. Resistant starch and "the butyrate revolution". Trends Food Sci Tech. 2002;23:251-61.

6. Rose DJ, DeMeo MT, Keshavarzian A, Hamaker BR. Influence of dietary fiber on inflammatory bowel disease and colon cancer: importance of fermentation pattern. Nutr Rev. 2007;65(2):51-62.

7. Slavin J L. Whole grain and human health. Nutr Res Rev. 2004;17:99-110.

8. Brown AJ, Goldsworthy SM, Barnes AA, Eilert MM, Tcheang L, Daniels D, Muir AI, Wigglesworth MJ, Kinghorn I, Fraser NJ, Pike NB, Strum JC, Steplewski KM, Murdock PR, Holder JC, Marshall FH, Szekeres PG, Wilson S, Ignar DM, Foord SM, Wise A, Dowell SJ. The Orphan G protein-coupled receptors GPR41 and GPR43 are activated by propionate and other short chain carboxylic acids. J Biol Chem. 2003;28;278(13):11312-9.

9. Gupta N, Martin P M, Prasad PD, Ganapathy V. SLC5A8 (SMCT1)mediated transport of butyrate forms the basis for the tumor suppressive function of the transporter. Life Sci. 2006;18;78(21):2419-25.

10. Tong X, Yin L, Giardina C. Butyrate suppresses Cox-2 activation in colon cancer cells through HDAC inhibition. Biochem Biophys Res Commun. 2004;317:463-71.

11. Zgouras D, Wachtershauser A, Frings D, Stein J. Butyrate impairs intestinal tumor cell-induced angiogenesis by inhibiting HIF-1 $\alpha$ nuclear translocation. Biochem Biophys Res Commun. 2003;300(4):832-8.

12. Bai L, Merchant JL. Transcription factor ZBP-89 cooperates with histone acetyltransferase $\mathrm{p} 300$ during butyrate activation of $\mathrm{p} 21^{\text {wafl }}$ transcription in human cells. J Biol Chem. 2000;30725-33.
13. Reeves P G, Nielsen FH, Junior GCF. AIN-93 purified diets for laboratory rodents: final report of the american institute of nutrition ad hoc writing committee on the reformulation of the AIN-76A rodent diet. J Nutr. 1993;123:1939-51.

14. Freeman HJ. Effects of differing concentrations of sodium butyrate on 1,2-dimethylhydrazine-induced rat intestinal neoplasia. Gastroenterology. 1986;91(3):596-602.

15. Rodrigues MAM, Silva LAG, Salvador DMF, Camargo JLV, Montenegro MR. Aberrant crypt foci and colon cancer: comparison between a short- and medium-term biossay for colon carcinogenesis using dimethylhidrazine in Wistar rat. Braz J Med Biol Res. 2002;35:351-5.

16. Bird RP. Observations and quantification of aberrant crypts in the murine colon treated with a colon carcinogen: preliminary findings. Cancer Lett. 1987;37:147-51.

17. Vale SR, Glória MB. Determination of biogenic amines in cheese. J AOAC Int. 1997;80(5):1006-12.

18. Smirick-Tjardes MR, Grieshop CM, Flickinger EA, Bauer LL, Fahey GCJr. Dietary galactooligosaccharides affect ileal and total-tract nutrient digestibility, ileal and fecal bacterial concentrations, and ileal fermentive characteristics of growing pigs. J Anim Sci. 2003;81:2535-45.

19. Liu R, Xu G. Effects of resistant starch on colonic preneoplastic aberrant crypt foci in rats. Food Chem Toxicol. 2008;46(8):2672-9.

20. Raju J, Swamy MV, Cooma I, Patlolla JM, Pittman B, Reddy BS, Steele VE, Rao CV. Low doses of beta-carotene and lutein inhibit AOM-induced rat colonic ACF formation but high doses augment ACF incidence. Int J Cancer. 2005;113(5):798-802.

21. Scharlau D, Borowicki A, Habermann N, Hofmann T, Klenow S, Miene C, Munjal U, Stein K, Glei M. Mechanisms of primary cancer prevention by butyrate and other products formed during gut-flora mediated fermentation of dietary fibre. Mutat Res. 2009;682(1):39-53

22. Kanna PS, Mahendrakumar CB, Chakraborty T, Hemalatha $\mathrm{P}$, Banerjee $\mathrm{P}$, Chatterjee M. Effect of vanadium on colonic aberrant crypt foci induced in rats by 1,2 Dimethyl hydrazine. World J Gastroenterol. 2003;9(5):1020-7.

23. Wallace H M, Niiranen K. Polyamine analogues - an update. Amino Acids. 2007;33(2):261-5.

24. Wallace HM, Caslake R. Polyamines and colon cancer. Eur J Gastroenterol Hepatol. 2001;13:1033-9.

25. Jang M, Cai L, Udeani GO, Slowing KV, Thomas CF, Beecher CW, Fong HH, Farnsworth NR, Kinghorn AD, Mehta RG, Moon RC, Pezzuto JM. Cancer chemopreventive activity of resveratrol, a natural product derived from grapes. Science, 1997;275(5297):218-20.

\section{Correspondence:}

Conflict of interest: none

Maria do Carmo Gouveia Peluzio

Universidade Federal de Viçosa

Departamento de Nutrição e Saúde

Av. Peter Henry Rolfs, s/n

36.570-000 Viçosa - MG Brasil

Phone: (55 31)3899-1275

Fax: (55 31)3899-2541

Received: March 17, 2010

mpeluzio@ufv.br

Review: May 18, 2010

Accepted: June 14, 2010

\section{How to cite this article}

Silva FGD, Penido LCP, Valente FX, Mendes MCS, Rosa DD, Glória MBA, Peluzio MCG. Sodium butyrate does not decrease the evolution of precancerous lesions in rats. Acta Cir Bras. [serial on the Internet] 2010 Nov-Dec;25(6). Available from URL: http:// $\underline{\text { www.scielo.br/acb }}$ 